\title{
Modelling Design Diffuser Horizontal Axis Wind Turbine
}

\author{
Fatahul Arifin ${ }^{1, *}$ RD Kusumanto ${ }^{2}$ Yohandri Bow ${ }^{3}$ Ahmad Zamheri ${ }^{1}$ Rusdianasari \\ Rusdianasari ${ }^{3}$ Min Wen Wang ${ }^{4}$ Afries Susandi ${ }^{3}$ Yusuf Dewantoro Herlambang ${ }^{5}$
}

${ }^{I}$ Department of Mechanical Engineering, Politeknik Negeri Sriwijaya, Jalan Srijaya Negara, Palembang, Indonesia ${ }^{2}$ Department of Electrical Politeknik Negeri Sriwijaya, Jalan Srijaya Negara, Palembang, Indonesia

${ }^{3}$ Department of Renewable Energy Engineering, Politeknik Negeri Sriwijaya, Jalan Srijaya Negara, Palembang, Indonesia

${ }^{4}$ Department of Mechanical Engineering, National Kaohsiung University Science and Technology, No. 415, Jiangong $R d$, Kaohsiung, Taiwan

${ }^{5}$ Department of Mechanical Engineering, Politeknik Negeri Semarang, Jl. Prof. Sudarto, Semarang, Indonesia *Corresponding author. Email :farifinus@yahoo.com

\begin{abstract}
The Wind power is one of the promising energy technologies, which can utilize wind energy as a source of renewable energy. So, in this case which a tool is needed, namely a wind turbine, but one of the problems that increase the wind speed in a low wind speed area. It must develop a device to increase the wind speed. Due to this case has been developed to use the Concept of Diffuser Augmented Wind Turbine (DAWT) to control wind speed in low wind speed areas now. With the difference in inlet pressure and outlet pressure, the diffuser is able to increase wind speed. In this case, a design simulation using ANSYS is shown to investigate the Horizontal Axis Wind Turbine (HAWT) performance in low wind speed areas by applying DAWT technology and modifying the diffuser angle. The diffuser angle variation was in the range $4^{\circ}-12^{\circ}$ and the diffuser length to diameter (L/D) was in $0.5 \mathrm{D}-1.0 \mathrm{D}$. The simulation results indicated a similarity with the literature which found the improved power.
\end{abstract}

Keywords: wind energy, diffuser, turbine

\section{INTRODUCTION}

One of the fast growing renewable energies is wind energy. Wind energy has long been recognized and applied by humans, for instance, for the power generation, but wind energy in the Indonesian region is categorized as low wind speed. However, wind potential in Indonesia is obtainable almost all over the year, making it possible to advance small-scale power generation systems. One of them is the manufacture of wind turbines, which will later help generate electricity and encounter the community's electricity requirements.

Many researchers have done the experiment by using the various type of wind turbine. Kamal et.al. used the four blade-blade Darrieus wind turbine for low speed area in Tanjung Enim South Sumatera [1], the Irawan et. al. studied three blade wind turbine for collecting wind in the settlement in Muara Enim [2]. Germana et. Al. applied the combination of
Savonius and Darrieus wind turbine in the mining area od PT. BA South Sumatera [3]. They found that wind turbine has the great future to develop in the South Sumatera area.

DAWT, Diffuser Augmented Wind Turbine, can be a promising solution to overcome those problems by adding a shroud to the turbine, then, might increase the power output of wind turbines [4-6]. DAWT technology has developed in the early 1950 s where the results obtained flow velocity 1.3 times higher than the freestream velocity [7]. These theoretical results were then carried out by experiments on small-scale wind turbines with a shroud and obtained an increase in power by $4 \%$ compared to without a shroud in wind turbines [8].

Putra et al [9] obtained the wind speed profile around the diffuser which earlier changed the diffuser in the form of supplementary inlet and flange curvature. Advance study on wind speed in 
DAWT was carried out by unpredictable the diffuser types, namely the camber diffuser and the uniform diffuser [10]. Ahmed et al [11] stressed the superiority of this DAWT performance where there are 3 diffuser design parameters that is able to enhance mass flow and wind speed, explicitly the length, height and the diffuser angle.

To solve the design problem some researchers such as Germana et. al [3] applied the Solidwork solve the problem in the design of the Savonius and Darrius turbine. Susandi et. al. [12] used ANSYS conducted the numerical study of the horizontal wind turbine.

In this study is to model the diffusers on horizontal axis wind turbines based on the angle and length of the diffuser. The analysis is made on a three blades horizontal axis wind turbine with the use of a diffuser with the angle $4^{\circ}, 8^{\circ}, 12^{\circ}$.

The purpose of this experiment to find the optimal design of diffuser of VAWT.

\section{METHODOLOGY}

The steps of the study are reviewing literature, running CFD simulation, designing and manufacturing wind turbine, finally collecting data. The flowchart of study can be seen in figure 1 .

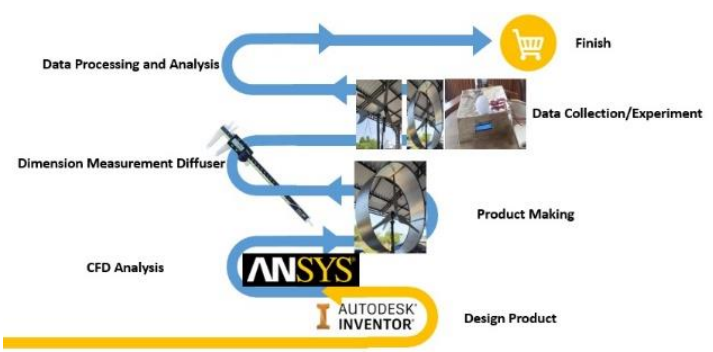

Figure 1 Research Flow Chart

The diffuser model assimilated three major parameters, which are, the inlet diameter of diffuser (D), the angle of diffuser $(\Theta)$, and the diffuser axial length (L). The diffuser used is shown in figure 2 . The diffuser length (L) is the distance between the diffuser inlet and outlet. The diffuser inlet diameter (D) is equal to the diffuser throat, which is the slimmest part of the diffuser.
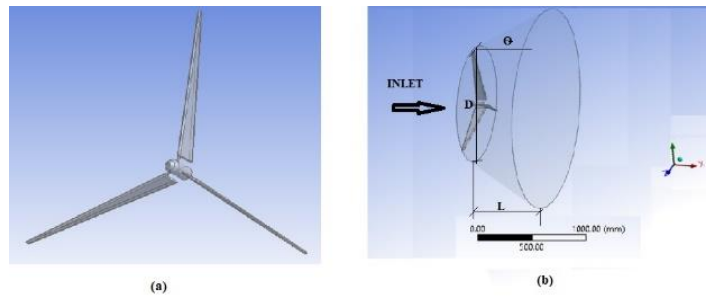

Figure 2 Modelling Design Blade and Diffuser of Horizontal Axis Wind Turbine

The equation 1 shows the calculation of the amount of power generated in the diffuser based on density, area, and velocity [7] (Bussel. (2007).

$$
P=\frac{1}{2} A \rho v^{3} C p
$$

Where; $P$ is power (W), $\rho$ is air density (1.225 $\left.\mathrm{kg} / \mathrm{m}^{3}\right), A$ is turbine swept area $\left(\mathrm{m}^{2}\right)$, and $v$ is wind speed $(\mathrm{m} / \mathrm{s})$, and $C p$ is coefficient of power. In this paper, $C p=0.59$ is the value of maximum theoretically for the wind turbine, which is called as the Betz Limit [13].

\section{RESULT AND DISCUSSION}

The wind turbine was experienced for a magnitude speed of $5.5 \mathrm{~m} / \mathrm{s}$ in Ansys Fluent. The contour of velocity variation inside the diffuser in this presented paper is shown in Fig. 5 at an angle of diffuser $4^{\circ}, 8^{\circ}, 12^{\circ} ; \mathrm{L}=1.0 \mathrm{D}$, and $\mathrm{D}=600 \mathrm{~mm}$. It is shown that in lower diffuser angle, i.e. $4^{\circ}, 8^{\circ}, 12^{\circ}$, the highest speed inside the diffuser $5.5 \mathrm{~m} / \mathrm{s}$, was assembly all over the place the wind turbine.

As shown in figure 3-4, the wind enters the diffuser with the high velocity and then out the diffuser with low velocity. The best profile velocity contour can be obtained at a higher diffuser angle, and then the diffuser length gave an excellent performance from $0.5 \mathrm{D}$ until 1.0D.

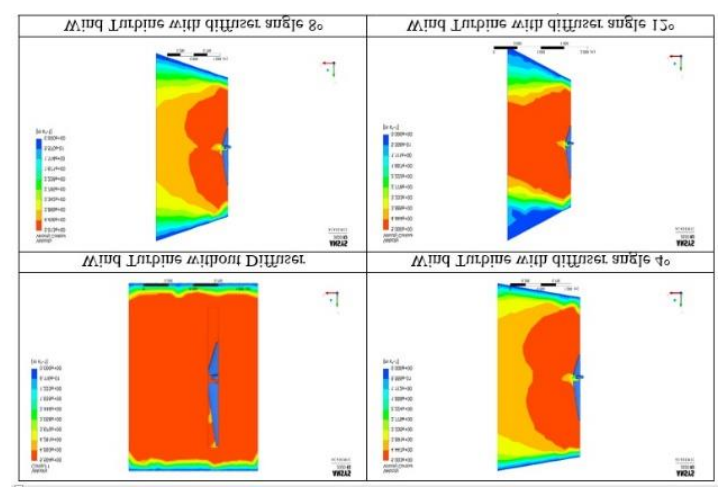

Figure 3 Wind Turbine without Diffuser and with diffuser angle $4^{\circ}, 8^{0}, 12^{\circ}$ 


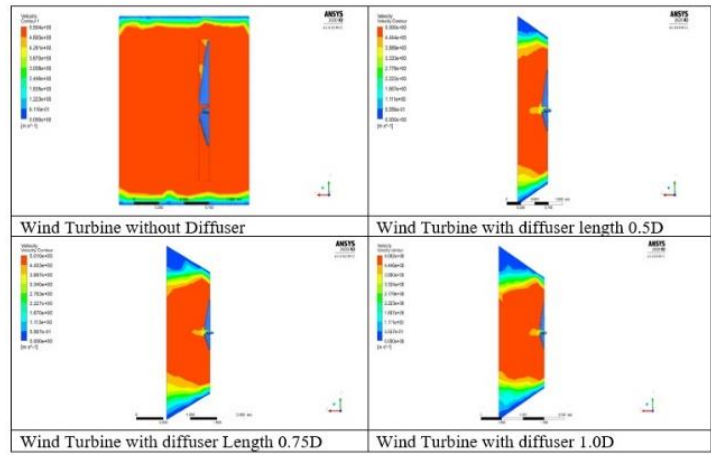

Figure 4 Wind Turbine without Diffuser and with Diffuser Length $0.5 \mathrm{D}, 0.75 \mathrm{D}, 1.0 \mathrm{D}$

The outcome directed the exist of the effect of diffuser angle into the increase speed inside the diffuser. Additionally, the contrast was also carried out with the non-diffuser wind turbine. The flow of velocity contour of non-diffuser wind turbine is shown in figure 3 and 4 . It can be seen that the nondiffuser wind turbine can only concentrate the mass flow of wind at the highest velocity. The best profile of shape velocity can be achieved at a higher diffuser angle. So, it directs that the diffuser augmented wind turbine can harvest more power than the base wind turbine and it is hopeful to install at low wind speed.

\section{CONCLUSION}

This investigation presents the CFD analysis of diffuser HAWT where the speed was calculated for dissimilar flow velocities and compared with those of non-diffuser wind turbine. The analysis express that the wind turbine performance, in view of the wind speed and generated power, is able to be significantly increased by placing it inside the diffuser. Based on simulations result, it can be concluded that a properly designed diffuser into HAWT is attractive and promising technology to increase mass flow of wind, particularly at low wind speed area.

\section{ACKNOWLEDGMENT}

This work is supported by the Ministry of Cultural and Education of Republic of Indonesia, Directoral of Vocational Higher Education, Politeknik Negeri Sriwijaya through Research Development Funding 2021

\section{REFERENCES}

[1] Kamal, M., Arifin, F., Risdianasar, (2021), Analysis of the Performance of The Four-Blade Darrieus Wind Turbine at the Jamik Bukit Asam Mosque Complex Tanjung Enim South Sumatra, International Journal of Research in Vocational Studies (IJRVOCAS) Vol. 1, No. 2,
August 2021 Print ISSN 2777-0168 Online ISSN 2777-0141 | DOI https://doi.org/10.53893/ijrvocas.v1i2.52

[2] Irawan, O., Bow, Y., Kusumanto, RD., (2021), Simulation and Performance Test Giromill Type Wind Turbine; Case Study Muara Enim, South Sumatra, Indonesia, International Journal of Research in Vocational Studies (IJRVOCAS) Vol. 1, No. 2, August 2021 Print ISSN 2777-0168 Online ISSN 2777-0141DOI https://doi.org/10.53893/ijrvocas.v1i2.10

[3] Garmana, A., Arifin, F., Rusdianasari, (2021). "CFD Analysis for Combination Savonius and Darrieus Turbine with Differences in the Number of Savonius Turbine Blades. International Conference on Artificial Intelligence and Mechatronics Systems (AIMS), pp. 1-5, DOI: 10.1109/AIMS52415.2021.9466009.

[4] Abe K. and Ohya, Y., , 2004, An Investigation of flow fields around flange diffuser using CFD," Journal of Wind Engineering and Industrial Aerodynamics, vol. 92, pp. 315-330

[5] Ohya Y., Karasudani,K., Sakurai, A. Inoue, M., 2006, Development of a high-performance wind turbine equipped with a brimmed diffuser shroud, Transactions of the Japan Society for Aeronautical and Space Sciences, vol. 49 (163), pp. 18-24,.

[6] Ohya,Y., Karasudani,T., Sakurai, A., Abe, K., Inoue, M., 2008, Development of a shrouded wind turbine with a flanged diffuser, Journal of Wind Engineering and Industrial Aerodynamics, vol. 96, pp. 524-539,

[7] Spera, D.A., Wind Turbine TechnologyFundamental Concepts of Wind Turbine Engineering, Second Edition. ASME Press, USA, 2009.

[8] Al-Quraish, B.A.J., Asmuin, N.Z., Mohd. S. Abd al-wahid, W.A., Mohammed, A.N., Didane, D.H., "Review on Diffuser Augmented Wind Turbine (DAWT)", International Journal of Integrated Engineering, vol. 11 (1), pp. 178-206, 2019.

[9] Putra, F.Q., Rifai,D., Suryopratomo, K., and Budiarto, R,. 2018., Multilevel Diffuser 
Augmented for Horizontal Axis Wind Turbine, E3S Web of Conferences (42), 01001,

[10] Klistafani, Y., Mukhsen, M.I., 2019, Development of Shrouded Wind Turbine with Various Diffuser Type Structures, IOP Conf. Series: Materials Science and Engineering (676) 012040

[11] Ahmed, B., Ahmed, A., Hussain, A., 2016, Modeling and Simulation of Diffuser Augmented Wind Turbine," 4th International Conference on Energy, Environment and Sustainable Development 2016
[12] Susandi, A., Arifin, F., Kusumanto, RD., (2021). Theory of Diffuser Parameters in the Performance of Horizontal Axis Wind Turbine using Computational Fluid Dynamics, Vol. 63, Issue 06, Journal Technology Reports of Kansai University

[13] Bussel, V.G.J.W., 2007, The science of making more torque from wind: diffuser experiments and theory revisited, J. Phys.: Conference Series 75 , pp. 1-12 